NBER WORKING PAPER SERIES

\title{
PAYMENT FOR ENVIRONMENTAL SERVICES: HYPOTHESES AND EVIDENCE
}

\author{
Lee J. Alston \\ Krister Andersson \\ Steven M. Smith \\ Working Paper 18740 \\ http://www.nber.org/papers/w18740
}

\author{
NATIONAL BUREAU OF ECONOMIC RESEARCH \\ 1050 Massachusetts Avenue \\ Cambridge, MA 02138 \\ January 2013
}

Forthcoming in the Annual Review of Resource Economics DOI: 10.1146/annurev-resource-091912-151830. The views expressed herein are those of the authors and do not necessarily reflect the views of the National Bureau of Economic Research. We thank an anonymous reviewer for comments. Lee J. Alston acknowledges support from the National Science Foundation Grant \#OISE 1157725) Krister Andersson would like to acknowledge financial support from the National Science Foundation, grants \# DEB-1114984, and BCS-0527165.

NBER working papers are circulated for discussion and comment purposes. They have not been peerreviewed or been subject to the review by the NBER Board of Directors that accompanies official NBER publications.

(C) 2013 by Lee J. Alston, Krister Andersson, and Steven M. Smith. All rights reserved. Short sections of text, not to exceed two paragraphs, may be quoted without explicit permission provided that full credit, including $\odot$ notice, is given to the source. 
Payment for Environmental Services: Hypotheses and Evidence

Lee J. Alston, Krister Andersson, and Steven M. Smith

NBER Working Paper No. 18740

January 2013

JEL No. Q15,Q54,Q57,Q58

\begin{abstract}
$\underline{\text { ABSTRACT }}$
The use of Payment for Environmental Services (PES) is not a new type of contract but they have become more in vogue because of the potential for sequestering carbon by paying to prevent deforestation and degradation of forest lands. We provide a framework utilizing transaction costs to hypothesize which services are more likely to be provided effectively. We then interpret the literature on PES programs to see the extent to which transaction costs vary as predicted across the type of service and assess the performance of PES programs. As predicted we find that transaction costs are the least for club goods like water and greatest for pure public goods like carbon reduction. Actual performance is difficult to measure and varies across the examples. More work and experimentation is needed to gain a better outlook on what elements support effective delivery of environmental services.
\end{abstract}

Lee J. Alston

Institutions Program

Institute of Behavioral Science

Department of Economics

University of Colorado at Boulder

Boulder, CO 80309-0483

and NBER

Lee.Alston@colorado.edu

Krister Andersson

Department of Political Science

Institute of Behavioral Science

University of Colorado, Boulder

Boulder, CO 80309

Krister.Andersson@colorado.edu
Steven M. Smith

Institute of Behavioral Science and Economics

University of Colorado, Boulder

Boulder, CO 80309

steven.m.smith-1@colorado.edu 


\section{Introduction}

There is a growing recognition that natural resources provide flows of services that provide economic value. Common environmental services (ES) that benefit societies include carbon sequestration, watershed services, biodiversity maintenance, and landscape beauty. Like other public goods, these services are often under provided, as most of the benefits are externalities. ${ }^{1}$ Governments could address these issues through regulation or tax/subsidy programs, but in the developing world, enforcement is often both costly and difficult. Moreover, the enforcement of noncompliant poor-populations is politically challenging. Alternatively, payment for environmental services (PES) is a policy tool championed to provide market incentives for the private upkeep of natural resources providing downstream users with environmental services. PES is defined as a voluntary agreement between a buyer and seller in which payment is given conditional on the environmental service being adequately provided (Wunder 2006). Many advocate the application of PES schemes to develop new-market based tools for combatting deforestation and encouraging forest conservation in the developing world over alternate policy tools. ${ }^{2}$ In the absence of these mechanisms, land users will lean towards commercial use of land, often involving deforestation for agricultural purposes, resulting in depletion of the natural resource as they have no way to monetarily realize the gains of providing the non-marketable services (Kroeger \& Casey 2007). The market type exchange looks appealing because: 1) land use changes in developing countries tend to be primarily a function of markets, not regulations (Alston \& Andersson 2011) and; 2) it is seen as a way to compensate the poor rather than regulating them. ${ }^{3}$ PES draws on the Coasian principle that with clear property rights and low transaction costs, bargaining can achieve the socially optimal level (Coase 1960). Often overlooked, Coase also indicates that when transaction costs are large and negotiation is prohibitively costly, government regulation may be the best alternative. ${ }^{4}$

The purpose of our paper is to first address the potential transaction costs for PES programs across different environmental services. Following the development of hypotheses we will review the extant evidence in the literature on PES programs. The ultimate question is: to what extent PES programs work, i.e. do they provide the environmental services or should other policies be pursued? At issue are the transaction costs. For many services targeted by PES programs the transaction costs may by high. The need for monitoring from an established baseline significantly increases transaction costs. In the case of environmental services (ES), property rights, are frequently unclear, especially in developing countries. Drawing on prior literature and our own insights, we discuss situations which can be expected to drive up

\footnotetext{
${ }^{1}$ We express caution here because the issue as Coase (1960) noted is: are goods underprovided compared to what alternative, and at what cost? Coase (1974) demonstrated that on the coast of England the "classic" public good, the lighthouse was provided privately for years and appeared to work reasonably well. In short, there are costs to using the market and costs of using government.

${ }^{2}$ See Wunder (2006) for a comparison of PES to other conservation tools.

${ }^{3}$ Landell-Mills \& Porras (2002) find that it is not always a win-win situation and the poor do not always gain.

${ }^{4}$ This is due to the fact that the transaction costs are larger than the gross surplus to be gained by the trade.
} 
transaction costs. The variables considered include both physical attributes and institutional settings. Interactions are important and it is unlikely that there is a one-size-fits-all solution (Agrawal, Nepstad \& Chhatre 2011). As a result we advocate adopting an analytical framework, such as the Social-Ecological System framework, which supports comparative research of PES (Ostrom 2009). Given this, it is important to assess the extent to which PES schemes can achieve their goal of additional conservation, paying careful attention to the interaction with the contextual setting to discover what situations work best. By and large, the ex-ante expectations are that transaction costs are largest in the case of carbon sequestration; lower for biodiversity service; and watershed services should pose the lowest transaction costs.

Experimentation with PES programs has begun in the real world in a variety of settings. Empirical analysis on their effectiveness remains somewhat sparse, but we review 18 studies to assess the performance of PES. ${ }^{5}$ The literature reviewed also provides a menu of techniques being employed to address issues of measuring service provided with particular attention to establishing additionality; i.e. how much additional environmental service is provided relative to the counterfactual of no program. Overall, we find mixed results, though the evidence supports our expectations of particular difficulties for carbon sequestration, including high transaction costs.

Finally, we assess our results in the context of the much touted initiative "Reduced Emissions from Deforestation and Forest Degradation” (REDD). This initiative seeks to address carbon emissions due to the loss of carbon sinks, particularly in developing countries which contain a large portion of the world's tropical forests. Deforestation is estimated to contribute nearly $20 \%$ of global carbon emissions (Palmer 2011). REDD has been expanded to REDD+ to include conservation and sustainable management to enhance forest carbon stocks. ${ }^{6}$ PES is currently a leading candidate for the implementation of REDD+. Incentives are seen favorably in this context due to the international nature of the issue and the inability to regulate sovereign nations. However, transaction costs are already high in carbon sequestration and the international setting, especially involving developing countries, drives transaction costs even higher (Alston \& Andersson 2011). It remains unclear if REDD+ can effectively sequester additional carbon for any meaningful time period.

\section{Transaction Costs and Property Rights}

Coase (1960) highlights the important role transaction costs have in dealing with social costs. Coase provided two key insights: the reciprocal nature of social costs and the importance of considering transaction costs when assigning rights, as they may impede otherwise beneficial transactions. In the context of PES, transaction costs include negotiation costs, often exasperated

\footnotetext{
${ }^{5}$ This builds on the cases included in the Ecological Economics special issue on PES (Vol. 64, no. 4). See Engel, Pagiola \& Wunder (2008) and Wunder, Engel \& Pagiola (2008) for the introduction and conclusion of the special issue.

${ }^{6}$ REDD++, a new extension, seeks to add low carbon but high biodiversity land to list of eligible projects.
} 
by the lack of clear property rights, monitoring (verification) costs and enforcement costs. Ultimately, the size of the transaction costs weighs heavily on the potential success of PES schemes. Where the transaction costs are large they may completely outweigh the private gains from a trade. In such cases, PES is not an efficient mechanism to achieve conservation goals. Here we assess ex ante expectations as to which scenarios present lower transaction costs. We consider the physical attributes of various environmental services as well as the institutional settings. Certainly there is some interplay between the two and specific institutions may be effective in reducing transaction costs for one service but not for others.

\subsection{Physical Attributes:}

In practice, most PES schemes target at least one of four environmental services: 1) Carbon sequestration 2) Watershed services 3) Biodiversity and/or 4) Scenic beauty. Initiatives targeting the first three are now somewhat common, while the fourth is rarely the primary goal. ${ }^{7}$ The physical characteristics of the service vary across these categories and impact the expected transaction costs.

These ecosystem services have attributes of a public good but to a varying degree. The scale of the public good has implications as to the number of people involved and the extent of the freeriding problem which accompanies it. Carbon sequestration provides reduced global warming. The reduction in atmospheric concentrations of carbon is one of the few examples of a pure public good. Reduced carbon is non-rival, as all those on the earth can consume the same unit of reduction. Not only can they consume the reduction, but everyone is forced to, as it is nonexcludable by nature. In this regard, one would expect the transaction costs to be large as the number of parties which need to negotiate is quite large, providing ample free-riding opportunities. In addition, nation states have very different preferences over climate change. In appealing to the definition of PES, carbon sequestration makes it difficult to identify the appropriate purchaser. The unproductive Doha climate talks in 2012 illustrate the difficulties of negotiating these global issues. In contrast, watershed services have been labeled a club good rather than a true public good (Wunder, Engel \& Pagiola 2008). A club good is non-rival and non-excludable, but on a smaller scale. In the case of watershed services, it is limited to those downstream (physically) within the same water basin. In this regard, it becomes simpler to identify the beneficiaries of improved watershed services and those that should be the providers of the service (Turpie, Marais \& Blignaut 2008, Van Hecken, Bastiaensen \& Vásquez 2012). With fewer possible providers and identified beneficiaries on both sides of the contract, transaction costs are expected to be lower and potential free-riding to be smaller than with carbon sequestration. Biodiversity services run the spectrum. In the pure case, it is a true public good like carbon sequestration in the sense that the potential gains from maintaining biodiversity can be consumed by all. However, in most cases where PES targets wildlife preservation, ecotourism is a central part to local economies. In these cases there is a private benefit to a broader

\footnotetext{
${ }^{7}$ The CSS program in the U.K. does target landscaping directly (Dobbs \& Pretty 2008).
} 
service, which provides a good which is marketable and profitable. ${ }^{8}$ In these instances, a beneficiary is easily identifiable providing a decrease in transaction costs and possible freeriding. Though, in contrast, in areas with no eco-tourism, biodiversity services will suffer the same free-riding issues as carbon sequestration.

In addition to the variation in demand, supply of environmental services also differs. Location and scale of land providing the service is integral to successful provision. Carbon sequestration exhibits a near-linear relationship in production with regard to the land enrolled. By planting one additional tree, or alternatively, not cutting one down in a young and growing forest, additional carbon sequestration is provided. This allows almost any plot of land to provide the service and one can target large plots of lands to reduce the relative transaction costs. ${ }^{9}$ Watershed services are considerably less fungible: location matters (Kroeger \& Casey 2007). The potential plots of land to provide the service are those upstream in the basin. This can reduce transaction costs by identifying a limited set of providers. However, watershed services do not exhibit a linear relationship with land enrolled (Swallow \& Meinzen-Dick 2009). The service provision is dependent on the activities on adjacent lands which are also in the upper water basin. Indeed, successful service may require all the land be enrolled, making it necessary to contract with all upstream parties, increasing the transaction costs. Biodiversity is also location dependent and non-linear in production (Nelson et al. 2010). Often scale is important and migration corridors connecting the landscape are crucial to the survival of wildlife. In this regard, biodiversity services are similar to watershed services, though the benefits often exhibit attributes of a public good rather than a club good.

A crucial element of an effective PES scheme is conditionality. The application of this principle requires monitoring and quantifying the service provided as well as enforcement for noncompliance. Naturally, this presents any provision with additional transaction costs, though this is not unique to PES as compared to other policy mechanisms. Measuring the flow of the environmental services is difficult, though easing thanks to improving scientific knowledge and technology. In practice, most services require some land management alterations and conditionality is employed at this level. While land use is easier to observe and measure, even this is subject to the question of additionality, whether payments induced additional inputs towards producing the service. We discuss later the use of the correct counterfactual or businessas-usual scenario.

Watershed services and wildlife preservation provide a more feasible setting for relatively low cost monitoring of output. Watershed services encompass quality, quantity, and reliability of

\footnotetext{
${ }^{8}$ Some evidence indicates that carbon sequestration provides co-benefits on a regional level, including watershed services and near-term regional climate stability (Stickler et al. 2009).

${ }^{9}$ By conserving the biomass in the forest, you also provide habitat to wildlife, as well as medicine, food, soil protection, and healthy nutrient cycles to locals.
} 
flow (Kosoy et al. 2007). All three of these are possible to test and measure in any given watershed, gathering both before and after data. Additional econometric controls may be necessary to infer causality. Turpie, Marais \& Blignaut (2008) note that the after the implementation of the Working for Water program, water flow increased 46 million cubic meters a year. Likewise, in situations aimed at augmenting species populations, sample counts could be taken and some idea of improvement in habitat quantified, as is done for a program in Cambodia (Clements et al. 2010). In contrast, measuring carbon sequestration and attributing it to one particular plot of land is less direct. The transaction costs are likely prohibitively expensive to truly quantify the service provided. In this regard, carbon sequestration will likely be relegated to conditionality on land coverage, relying on scientific estimates of sequestration.

\subsection{Institutional Attributes}

PES schemes may be pursued in various institutional settings and vary in their institutional structure as well. In regard to design, the source of funding is an important distinction among PES schemes (Corbera, Soberanis \& Brown 2009, Engel, Pagiola \& Wunder 2008). Broadly, the source of funding is either coming from the user or through the government. User-financed programs are expected to have relatively larger transaction costs than government-financed programs because of economies to scale in transaction costs. A large portion of the transaction costs are in start-up costs (Börner et al. 2010, Hegde \& Bull 2011, Wunder \& Albán 2008). Given that government programs are typically larger than private programs, they enjoy economies of scale in reducing transaction costs per service provided (Blackman \& Woodward 2010, Wunder, Engel \& Pagiola 2008). Allowing the government to negotiate reduces the number of parties directly involved while controlling the free-rider issue through the power of taxation or regulation. User-financed programs struggle to initiate due to large start-up costs. While government funded programs tend to have lower negotiation costs, there is a concern that other transaction costs may be higher; in particular monitoring costs and, at times, enforcement costs. User-financed programs value the service enough to take on costly transactions to receive the service, suggesting an incentive to also monitor the service and ensure it is provided and enforced (Corbera, Soberanis \& Brown 2009). Vatn (2010), along the lines of Coase (1960), argues that it is only an "efficiency net" of the transaction costs or in Coasian terms, all transaction costs need to be fully considered in assessing social costs. Given the scales of economy on transaction costs, it may not be entirely accurate -as suggested by some scholarsto classify user-financed programs as more efficient.

\subsubsection{Property Rights}

At the core of Coase (1960) is the assignment of property rights. In the case of PES, the property rights over the "externality" become clearly defined in that the potential provider has the right not to provide the environmental service. ${ }^{10}$ What remains less clear, is exactly who owns the

\footnotetext{
${ }^{10}$ Because of the reciprocal nature of costs, Coase never used the term externality.
} 
rights to manage the land from which the environmental service flows, particularly in developing countries. Often, there is a split between de jure property rights and the de facto property rights. In many situations the land is government owned or the private land is regulated but these de jure statutes are not enforced (Galudra et al. 2011). In addition, rights that are enforced locally, are often without judicial backing by formal legislation (Alston \& Andersson 2011). The issue is critical because as much as $2 / 3$ of future deforestation is predicted to occur where tenure is illdefined (Börner et al. 2010). Given the government's inability to enforce de jure rights over de facto rights, there arises an incentive to have user based PES plans that include all the owners and users of the resource (Muñoz-Piña et al. 2008).

Many PES programs have been implemented where the activity is already required by law, but poorly enforced (Börner et al. 2010, Clements et al. 2010, Honey-Roses, Baylis \& Ramirez 2011, Turpie, Marais \& Blignaut 2008, Wunder \& Albán 2008). Property rights must be established prior to the PES program, though some scholars submit that only rights over the service flow (or de facto use rights) are needed, not the actual land ownership (Lyster 2011). For instance, in the context of carbon sequestration, there is consideration of "carbon rights," creating an asset of the carbon sequestered in the vegetation of the land separate from the land itself. This framework provides a mechanism to give indigenous forest users access to the PES market for activities on state owned forest. Karsenty, Vogel \& Castell (2012) provide a good discussion of this issue and overall find it lacking due to the concept being poorly defined. The authors note that providing use rights separately may provide leverage to future land tenure reform, but also may crowd out the local users. They reaffirm other scholars' position that having secure rights of exclusion and management is sufficient to successfully provide the service and engage in projects (Mahanty, Suich \& Tacconi 2012, Palmer 2011, Swallow \& Meinzen-Dick 2009, Wunder 2006). For instance, individuals renting land comprise 1/3 of the participants of a PES scheme in the UK (Dobbs \& Pretty 2008). Engel \& Palmer (2008) provide an example in Indonesia where communities, with unclear tenure, are able to exclude logging operations and effectively issue logging permits. That said, security of tenure does exert the largest influence on the likelihood that a provider will opt into a PES program (Zbinden \& Lee 2005). Furthermore, the security of the tenure may not be exogenous, as the presence of a PES program can add value to the land and provide the incentive to establish property rights (Alston, Harris \& Mueller 2012, Engel \& Palmer 2008).

While clear property rights are necessary, private property rights are not. Communal property rights offer economies in scale of transaction costs much as government-financed programs do. Transaction costs can be reduced by enrolling large sections of lands rather than many individual smaller plots. In this respect, communal land actually provides a mechanism which reduces transaction costs (Akiefnawati et al. 2010, García-Amado et al. 2011, Swallow \& Meinzen-Dick 2009). The effectiveness of such deals depends on the ability of the community to engage in cooperation and ensure delivery of the service. To this end, PES activities are likely to function 
better in communities with proven success in cooperation, or at least that exhibit attributes associated with successful resource governance (Mahanty, Suich \& Tacconi 2012, Ostrom 2009).

\subsubsection{Monitoring and Leakage}

Issues with monitoring and actual performance are one of the largest hurdles in a PES program. Engel, Pagiola \& Wunder (2008) highlight many of the issues. For one, it is difficult to measure the service itself. An alternative, used by many programs, is to make payments conditional on inputs rather than outputs. Focusing on a change in land use is easier to observe than measuring the elusive service that it provides. Notably, technology is making this process more transparent, reducing monitoring costs. With the increased availability of satellite imaging, it is possible to remotely assess changes in land usage. Even with the increasing ease afforded by monitoring inputs, it remains difficult to establish a credible counterfactual. That is, how much additionality is achieved through the payments versus what would have occurred in the absence of the program? In a market type situation, additionality is important, or else payments merely transfer wealth with no additional service provided. ${ }^{11}$ Additionality is easier to identify and monitor in programs which focus on changing current land use rather than payments to avoid possible future changes, such as deforestation, lowering the transaction costs (Richards \& Andersson 2001). The lack of low-cost monitoring technology presents a large hurdle to the effectiveness of any market based system of ecosystem provision (Kroeger \& Casey 2007). While monitoring inputs provides a cheaper option aided by technological advances (Stickler et al. 2009), it does not ensure the service purchased is actually provided, presenting a possible trade-off in transaction costs and effectiveness.

Programs may be more effective when they are larger in scale by minimizing leakage (Busch et al. 2012, Sierra \& Russman 2006, Swallow \& Meinzen-Dick 2009). Leakage in small PES programs may occur for two reasons. First, an individual land owner may enroll part of their land in a program and then engage in production of private goods on an alternative plot of land that would have otherwise provided the environmental service. Potential leakage is smaller for watershed programs for which only specific plots of land impact the service. Programs can address this issue by incorporating clauses while negotiating the contract. Being more specific in the contract may raise transaction costs in negotiation, but contracting over larger plots of land reduce transaction costs per hectare as discussed previously. The second type of leakage is due to the influence of the market. If supply of a good is reduced, market prices increase and induce other independent land owners to bring marginal land into production. For instance, the United States Conservation Reserve Program (CRP), which pays farmers to take land out of production, is estimated to suffer 20\% leakage (Claassen, Cattaneo \& Johansson 2008). A closer screening of the exact nature of the transaction costs of all parties entailed may reduce this leakage or, alternatively as Coase (1960:39) noted: sometimes "it costs too much to put the matter right."

\footnotetext{
${ }^{11}$ Some proponents of PES argue those providing the service should be compensated regardless of whether it is additional or not (Pfaff, Robalino \& Sanchez-Azefeifa 2008, Andersson \& Richards 2001).
} 


\subsubsection{Poverty Reduction}

Many programs, especially those government-financed, aim to alleviate poverty in addition to providing an environmental service. When considering the effectiveness of a program in producing the ES, the pro-poor performance is secondary. However, to the degree that poor populations have influence on the state of the land condition, it is important to consider the impact on them and work to align the incentives of all parties involved (Akiefnawati et al. 2010). In cases in which incomes are improved and poverty is reduced there is an incentive for individuals to assist in providing the service rather than to undermine the project. Ultimately, this reduces the need for extensive external monitoring, helping to reduce transaction costs. The importance of poverty as a secondary goal is greater in situations where property rights are less clear. It is important that payments compensate users and "owners" for their opportunity costs, otherwise the "owners" have incentives to accept payment but not monitor. Coomes et al. (2008) indicates that some programs fail to compensate opportunity costs properly, making them unlikely to succeed. Communities may engage in collective action to subvert the program rather than to support it when they are not sufficiently compensated (Swallow \& Meinzen-Dick 2009). While not the main goal, if programs do not provide sufficient payment and monitoring is difficult, cheating and leakage will be more prevalent.

\subsubsection{Nested Institutions}

Developed nations typically enjoy lower transaction costs for PES programs because extant institutions are in place and there is greater clarity on land tenure. Due to larger incomes, there is an ambiguous impact on the likely success of a PES program. On one hand, higher productivity and prices will cause opportunity costs to be larger, making the necessary funding amount greater. However, as the environment is often seen as a luxury good, some conservation may occur naturally. In the setting of a PES scheme, this questions the amount of additionality which may be achieved. Furthermore, even in developed countries the process of monitoring remains difficult (Claassen, Cataneo \& Johansson 2008, Dobbs \& Pretty 2008).

The form of contracts and negotiation can have great influence on the effectiveness of a PES program. One obvious condition to create an effective program is conditionality. If the service is not provided, payments should cease. But this entails both monitoring and enforcement costs. Timing is also important. Often there are large upfront costs in conservation, particularly when it requires active land use change rather than passive. In poor populations who are financially constrained, even a lucrative long term conservation deal will fail if early payments do not cover the upfront labor and opportunity costs.

While PES programs may provide an incentive to develop more secure property rights, the introduction of payments can result in perverse incentives, increasing degradation and crowding out social behavior. Introducing payments into a setting which operates on social capital may 
undermine prior cooperation. While providing a good review of the experimental literature on this regard, Bowles (2008: 1605) states that the economic policy design often "overlooks the possibility that economic incentives may diminish ethical or other reasons for complying with social norms and contributing to the common good.” Kerr, Vardhan \& Jindal (2012) finds elements of this in field experiments conducted in Mexico and Tanzania amongst communities familiar with PES schemes. Overall they find that low individual payments crowd out participation in communal projects compared to situations with no mention of cash. Furthermore, they find that those participating in the communal task for payment are less satisfied with the process than those volunteering their time. At the local level, providing in-kind compensation, rather than incentive payments, may reduce the breakdown in social norms (Van Noordwijk \& Leimona 2010, Vatn 2010). García-Amado et al. (2011) find that participants cite the income as the third most important reason they engage in conservation. While this aspect introduces questions of additionality and motivation, the other concern is that in the presence of PES schemes degradation increases by individuals seeking to establish additionality (Richards \& Andersson 2001). Once it becomes clear that marginal land is worth something under a PES scheme, but only if it will be altered, individuals may begin to modify land use strategically in order to become eligible. Or, alternatively, they may resort to blackmail directly, threatening to deforest unless compensated (Karsenty, Vogel \& Castell 2012)

Designing a PES which works at various levels can reduce transaction costs by limiting the number of parties negotiating while utilizing local knowledge on how to cost-effectively meet the targets. The nesting of institutions provides this opportunity. Choosing the proper compensation form at the various levels can aid in making a more effective program. Van Noordwijk \& Leimona (2010) differentiate compensation into three broad categories: 1) Commoditized environmental services (CES) provides funds conditional on the service being provided; 2) Compensating opportunities skipped (COS) derives payments conditional on inputs actually being employed; and 3) Co-investment in land stewardship (CIS) operates on trust with the local users providing, often non-monetary, incentives to engage in environmentally friendly practices. According to Hoang et al. (2012), employing CES with cash payments at the top levels, such as the central government to the districts, can be effective. At this level, land ownership is clear and which district is producing the service is clearly identified. Farley et al. (2010) found this technique to work well in the context of Brazil's ICMS ecologico program. From the district level to levels further down Hoang et al. (2012) suggest that COS or CIS may be more appropriate to allow negotiation and flexibility at the grass roots level. These can overcome obstacles discussed earlier, such as costly upfront costs, or, using CIS, avoid using money directly and the perverse incentives which it may introduce. Agrawal, Nepstad \& Chhatre (2011) point out the importance of engaging multiple levels of actors; the state often maintains de jure property rights but sometimes decide to devolve some management rights to more local levels. White \& Martin (2002) estimate that most of the forest in developing countries are publicly owned, $79 \%$, though only $71 \%$ is managed by the state. The remainder is private with $14 \%$ held communally and $7 \%$ held individually. 


\subsection{Interaction of Physical and Institutional Attributes}

Drawing on Ostrom's (2009) Social-Ecological System's framework, attributes of the service will interact with the institutional structure to impact the level of transaction costs and ultimately the likelihood of success. Scholars already advocate applying the framework and lessons learned in the context of common pool resources and social-ecological systems to PES (Fisher et al. 2010, Yin \& Zhao 2012). These considerations could guide program design in order to maximize the environmental service targeted. Ostrom's SES framework is a diagnostic tool for policymakers as well as a framework that needs further hypothesis testing. For example, as mentioned above, the tenure situation is of first order importance before establishing a PES scheme. Another factor is the resource context: PES programs for carbon sequestration may need different strategies from programs for other environmental services. In short the SES framework is a "living" framework that needs testing to verify which contexts matter the most. The SES framework can guide research and policy but it is not a blue-print. Practitioners and academics need to be aware of the both the strengths and weaknesses of the SES framework.

One big split in the PES debate is user-funded versus the government-funded programs. Overall, user-funded programs appear better suited for water services. In these cases, the group of users and providers are easy to identify. In this context, incentives are compatible because those downstream truly desire better quality water or more reliable sources of water. In this situation, conditionality is likely to be enforced. Because of the limited geographic scope of the service, local groups can utilize their knowledge of the situation to come up with a PES scheme, alleviating the need for a central government to try to impose a system across all the watersheds. ${ }^{12}$ Carbon sequestration, on the other hand, needs government programs more to handle the public good. Large programs can benefit from economies of scale on transaction costs and provide additional monitoring to ensure quality of the service.

Given the difficulty of directly measuring carbon sequestration and establishing additionality of avoided deforestation, programs can reduce transaction costs by focusing on reforestation. While initially more expensive due to labor and inputs, the question of additionality is alleviated and land use changes are easy to monitor. Of course, this could lead to perverse incentives in existing forest land, making it necessary to assess the overall importance of additionality. In contrast, because location and type of vegetation are important to biodiversity and watershed services, these programs cannot focus only on reforestation, as precise pieces of land need to be maintained and improved, such as wildlife corridors.

Currently the state of the literature is long on potential hypotheses about the ingredients for successful PES programs but much more empirical work needs to be done in order to provide generalizable hypotheses for policy makers.

\footnotetext{
${ }^{12}$ Brazil actively moved to watershed management in the late 1990s with some central government oversight.
} 


\section{PES in action: Will it work? Is it working?}

PES programs have recently been implemented across various settings targeting an assortment of environmental services. We surveyed a selection of studies of PES from around the world targeting a variety of environmental services to analyze whether programs succeed in delivering additional ES while considering the extent of the transaction costs. Noticeably, the sample is small, consisting of 18 studies analyzing 16 programs. We also report on an additional four studies which use simulation and valuation methods to assess the potential feasibility of PES programs. The small sample is an artifact of the paucity of programs and the difficulty of analyzing them. Researchers struggle with the same measurement issues as program administrators: measuring the flow of the service and establishing additionality. In fact, most studies rely on input measures rather than output. Researchers try to address additionality in their studies by carefully defining the counterfactual. The sample is not large enough nor similar enough to perform rigorous meta-analysis, instead we present the techniques used and highlight some key points. Ultimately, most of researchers perceive some positive amount of environmental service, though the extent and efficiency of the programs vary. Table 1 summarizes the empirical studies assessed.

\subsection{PES Feasibility}

Some work has been done to assess the economic feasibility of PES programs. The basic economic criteria necessary is that willingness-to-pay (WTP), the monetary utility derived from consuming the service, be greater than the willingness-to-accept (WTA), the marginal cost of producing the service. ${ }^{13}$ Van Hecken, Bastiansen \& Vásquez (2012) focus on the demand side, conducting a contingent valuation survey of water users in Nicaragua. They find the WTP is significant; however, users are willing to pay more for infrastructure improvements rather than payment to land owners upstream. Börner et al. (2010) find similar results in Brazil concerning carbon sequestration; the economic underpinnings exist (WTP exceeds WTA), but the local institutions are not as conducive to a PES scheme. In contrast, Coomes et al. (2008) finds that it is not economically prudent to reforest in Panama given the return on grazing cattle. Looking at the net present value of income streams from both reforestation and cattle grazing over 25 years they find reforestation is slightly better but the timing of the payments make it difficult for financially strapped farmers to participate. Without access to capital markets the trade-off between upfront costs of reforestation and upfront benefits of cattle grazing is difficult to make despite the long term benefits.

Busch et al. (2012) performs simulations of various policies designed to reduce carbon emissions in the context of Indonesia. They consider what would have happened from 2000-2005 by calibrating a model of observed deforestation and spatial variation in economic benefits of land conversion. While they find that a mandatory tax/subsidy at a global market rate reduces

\footnotetext{
${ }^{13}$ Often the WTA estimates consist of the opportunity cost, referring to the income foregone when choosing to provide service rather than alternative economic activity.
} 
emissions 26\%, a voluntary PES system only cut emissions by $8 \%$. The voluntary performance improved to $22 \%$ reductions when contracts targeted larger plots of land (reducing leakage), monitoring techniques improved, and nested institutions were employed to share both costs and benefits. The cost sharing supports Palmer's (2011) argument that sharing liability between levels will help decrease leakage and increase permanence. Ultimately, the results here bring the effectiveness of PES schemes into question. As such, we turn to studies which have explored individual cases in order to assess the effectiveness.

\subsection{Costa Rica’s PSA program}

Costa Rica claims one of the earliest implementation of a PES program in the developing world. The Pagos por Servicios Ambientales (PSA) program began in 1997. The program is an umbrella program in the sense that it targets multiple services; the program seeks to improve the provision of carbon sequestration, hydrological services, biodiversity and scenic beauty, with the government gaining the rights to any carbon sequestration (Pagiola 2008). It is difficult to assess the effectiveness of a particular resource service, but its age and longevity has led to a relative abundance of analyses. The various studies provide a good sample of techniques being used to assess the efficacy of PES programs. Overall, the results are not glowing on actual performance. Three of the five studies included found negative, or at best, marginally positive outcomes, with the other two finding positive outcomes. Notably, additionality is weak across the studies with leakage undermining the efficiency of the program. Targeting multiple services makes it difficult to select the appropriate land to enroll.

The two techniques most commonly used for assessment are econometric analysis of either household survey data or satellite data. Satellite data is seen as a promising technological improvement allowing for lower cost monitoring, though is limited to quantifying inputs rather than output directly. Utilizing econometric analysis, regardless of the data source, seeks to create a more accurate business-as-usual scenario by including similar observations not enrolled in the PES. Locatelli, Rojas \& Salinas (2008), Sierra \& Russman (2006) \& Zbinden and Lee (2005) all utilize household level surveys to analyze PSA.

Sierra \& Russman (2006) includes non-participants in the sample and use regressions, controlling for attributes which influence deforestation, and find no discernible difference in forest coverage between participants and non-participants. Locatelli, Rojas \& Salinas (2008) find a positive overall effect, though they limit their sample to those under reforestation contracts, making it easy to assess the change in land use. Using fuzzy multi-criteria analysis they focus on other outcomes, finding the economic impact negative and that the poor population does not benefit, bringing the sustainability of the program into question. Notably, though, they find that land tenure became more secure, underscoring the endogeneity of property rights. Zbinden \& Lee (2005) use their survey of participants and non-participants to highlight the selection bias of participants. The well off, better educated, more off-farm income, and more secure tenure on larger plots of land tend explain a large part of the odds of participating, 
whereas physical attributes of the land, such as degradation and slope are less influential. Overall, the evidence brings into question the additionality being achieved.

Pfaff, Robalino \& Sanchez-Azefeifa (2008) utilize objective satellite imagery rather than household surveys, to analyze the impact on deforestation. In order to utilize an accurate counterfactual they use matching techniques based on the physical attributes and access to economic activity. Overall, they find the land enrolled tended to be at low risk of deforestation based on observables, finding that $99.92 \%$ of it would have been conserved anyway due to lack of market opportunities for much of the enrolled land. Ultimately, this implies that only $0.08 \%$ of the funds were effective in altering land use changes and the rest was simply a transfer of funds. Finally, Pagiola (2008) approaches the issue by exploring the literature surrounding PSA, finding that additionality is probably weak, but institutions do improve, e.g., property rights to land became more secure, and it is important to compensate those providing the service. While not every program shares the same lackluster performance in additional service provision, the techniques utilized across these studies provide an excellent idea of the tools used in assessing PES schemes.

\subsection{Water PES Programs}

Six programs targeting watershed services from the United States, Latin America, China, and South Africa are included here. Of the three programs in Latin America, only the Mexican Program for Hydrological Environmental Services (PSAH) is government-funded. The authors attribute this to the regional provision of the public good making the identification of the beneficiaries difficult. As suspected, this program provides the lowest transaction cost of the group at 4\% (Muñoz-Piña et al. 2008). In contrast, the Program for Sustainable Agriculture on the Hill Sides of Central America (PASOLAC) in Nicaragua, Honduras and Costa Rica as well as the Pimampiro project in Ecuador are both funded by users downstream. Kosoy et al. (2007) underscore the potential use of PES in watershed services finding the users had a willingness to pay much higher than the payments they were making. In Ecuador, Wunder \& Albán (2008) find the program to be effective and highlight a few distinctions. First, despite the higher transaction costs, the user-funded program appears closely monitored with payments denied due to the lack of provision. Secondly, they find low levels of leakage attributed to the nature of the watershed and lack of other land that would offsets improvements.

The watershed programs in China and South Africa are both organized by the government. The Sloping Land Conversion Program (SLCP) is a large program in China aimed at improving water quality and flood protection by removing sloped land from production and reforesting it. The government involvement comes from the sheer size of the program, designed to remove 14.67 million hectares from production. Given the poor population which used this land and no intermediate land use options, the government is relocating populations to off-farm industries. This project has been criticized for its inability to meet its targets in a sustainable manner (Yin \& Zhao 2012). Groom \& Palmer (2012) note that the poor population has seen an increase in 
income, begging the question as to why they did not migrate prior to the program. The authors suggest this setting is odd due to the authoritarian government of the Chinese. ${ }^{14}$

In contrast, the Working for Water Program (WFW) in South Africa is seen by many as a success (Turpie, Marais \& Blignaut 2008). The program is unique, in that it bypasses property rights issues by paying for labor rather than land owners foregoing production. The transaction costs are low, and it should be noted that WFW was designed as a poverty relief mechanism to employ the unemployed. Furthermore, the government funded it because the vegetation needing removal should have been removed by the land owners by regulation. However, this is not enforced and much of the land actually belongs to the state. Somewhat unique is that the provision required the removal of an invasive species, making monitoring of the task much more clear and straightforward.

Finally, the Conservation Reserve Program (CRP), organized by the U.S. Department of Agriculture, was designed to reduce soil erosion and subsequent water issues among other services. Overall, the program works with farmers to convert highly erodible cropland to vegetative cover in order to reduce soil erosion and thus improve water quality and groundwater recharge. The program also aims to provide some wildlife services as well. Claassen, Cattaneo \& Johansson (2008) find that the program is effective in achieving additionality. The program strives to enroll land which will gain the most impact per dollar relying on bids which calculate the Environmental Benefits Index (EBI) of each bid, considering the cost of providing the service. While upfront more expensive, the EBI permits greater cost-effectiveness. Even with the upfront costs of the EBI the program exhibits very low transaction costs, just $1 \%$ of the program's costs, due to the pre-existing institutions and the scale of the program. However, there remains a trade-off with these transaction costs; even in this developed world setting, monitoring remains quite low. A program this large exerts forces on the crop markets. The decrease in supply forces prices up, inducing others to enter. The study suggests that for every 100 acres enrolled in the program 20 acres elsewhere are brought into production.

\subsection{Wildlife Habitat/Biodiversity PES Programs}

Almost all biodiversity/wildlife programs are government funded. In most cases, these programs target general biodiversity, making the government necessary as beneficiaries are not clear and subject to free-riding. The one which is user-funded is unique in that it is the most Coasian of the bunch and involves negotiation over a single contract where a marketable good correlates with the service. We discuss this project last.

In the developed world setting, Countryside Stewardship Scheme (CSS) is a PES program in the UK that enrolls landholders to provide wildlife services and notably, is the only PES program we found that explicitly targets the provision of landscape beauty (Dobbs \& Pretty 2008). The program grew rapidly and just 13 years after its start, it had entered into over 16,000 contracts to

\footnotetext{
${ }^{14}$ In fact, this program may not fit the PES definition as participation does not appear to be voluntary.
} 
cover more than 50,000 hectares. The authors note that most of the enrolled farmers were running relative small-scale, low-input farming operations and the CSS has had relatively limited success in attracting highly industrialized agricultural operations to enroll in the CSS. This shortcoming is, according to the authors, largely attributable to the availability of competing payments in the form of generous agricultural subsidies from the EU's Common Agricultural Policy. The authors review the evidence on the extent to which CSS produced environmental additionality, and find that about 75 percent of all enrolled farmers carried out conservation activities that would not have taken place, at least not at the same scale, in the absence of the CSS payments. The authors also note, however, the inherent methodological challenges in quantifying such additionality: to determine the value of the resources that would not have been conserved had it not been for the payment.

Clements et al. (2010) explore three PES schemes in Cambodia in a small region, all targeted at protecting the habitats of a bird species. Given this specific target, the service is quantifiable and all three programs resulted in more nests and more birds. Again, the government provides additional incentives here as the villages targeted are all inside "paper parks" where the protection should already exist. The findings support the use of a variety of payment schemes, as both sharing eco-tourism revenue with the locals and providing a certification for market goods improved the habitats over the long term. The third technique was to pay individuals to guard the nests from poachers; this was effective immediately, though long term sustainability is questioned. It does reaffirm the cheap, low transaction cost, option to include those without clear property rights and that people respond to economic incentives more than regulatory constraints. The use of payments for labor can complement payment to holders of property rights, including a greater number of locals while providing greater odds of success (García-Amado et al. 2011). Not only does the extra payment reduce the non-property rights holders need to illegally harvest forest products, but they also have an incentive to help enforce the policy. Aligning the incentives of more users, both de jure and de facto, increases the odds of success. The inclusion of labor payments has been effective in doing so.

Honey-Roses, Baylis \& Ramirez (2011) employ satellite imaging and illustrate the need to construct an accurate counterfactual. In assessing the impact of paying communities to protect the Monarch Butterfly in Mexico, they match plots of land based on physical characteristics and consider what is occurring on adjacent plots. Without this, they find no improvement in forest coverage, but once they match observations to create a baseline of potential deforestation, they find evidence of additionality. While this highlights the need to consider the business-as-usual scenario for avoided deforestation, it does not indicate that doing so will create a more positive outcome. These results contrast with Pfaff, Robalino \& Sanchez-Azefeifa (2008) who find no additionality. Controlling for potential deforestation Pfaff, Robalino \& Sanchez-Azefeifa (2008) found the impact of the PSA program small, indicating land under little stress was more likely to enroll in the program. We highlight that additionality results are likely dependent on the setting, 
but both examples illustrate a need to consider the appropriate counterfactual to establish additionality.

The outlier of the group is the single contract in Tanzania between a user and provider (Nelson et al. 2010). The contract represents a quintessential example Coasian type negotiation where clear property rights aid in contracting. Unlike the other cases of biodiversity, this service provides a direct financial benefit to tour companies, creating a quasi-private good. Unlike other userfunded programs, the transaction costs were low. This should be of no surprise, for if they were not, the deal would not have been sought. Pre-existing relationships appear to have kept down the negotiation costs. Tour guides in the area became concerned that land owned by the village, which historically was undeveloped, began to be cultivated and settled. The region is an important grazing land for the animals which the tours like to showcase, but is not directly accessible to tours. This distinguishes it from other concessionary agreements which they have with villagers to take tours on their land. However, given these prior agreements there was some past interactions which made the new negotiation possible. The tour guides simply paid the villagers a set amount each year to not cultivate or establish permanent settlement. The deal included additional funds to pay for monitoring and guards. While no count on the increase of animals is available to truly assess the environmental impact of the contract, the land has maintained its natural state and the funds have been used to prosecute invaders from other villages, both marking a change in behavior.

\subsection{Carbon PES Programs}

The three programs included in the study which assess PES programs for carbon sequestration have notably high transaction costs. The Carbon Livelihoods Project in Nhambita, Mozambique stands out with transaction costs estimated to constitute $66 \%$ of the total costs (Hegde \& Bull 2011). The evidence confirms our ex ante expectations of carbon sequestration programs having the largest transaction costs due to the pure public good nature and difficulty in monitoring and enforcement. They find that the program decreased agricultural activity and deforestation based on surveys of participants and non-participants, noting that households do see an increase in income and their opportunity costs covered. Furthermore, Groom \& Palmer (2012) offer some evidence of additionality despite the transaction costs. Both papers attribute some of the success to the menu of the options available to land-holders, allowing them to pick the technique of provision most suitable to their needs. There is concern with the large transaction costs that the providers are not receiving enough of the funds to make the program sustainable.

The other user-funded carbon program considered is the PROFAFOR project in Ecuador (Wunder \& Albán 2008). This too is seen as a success in terms of additionality and lack of leakage. The Dutch company seeking carbon credits actually monitors the individual plots of 
land each year measuring forest coverage. ${ }^{15}$ As this is user-funded, they have some incentive to ensure that the service is provided. In order to reduce leakage and transaction costs, the program only allows plots of 50 hectares or more to be enrolled. The Dutch also considered biophysical attributes to target plots which would provide more additional sequestration.

The last program, Program of Payments for Carbon, Biodiversity and Agro-forestry Services (PSA-CABSA) in Mexico, is government funded. Thus far, it appears to have had some positive impacts, though the extent and continuation is not clear (Corbera, Soberanis \& Brown 2008). Funding has dropped off considerably. The program, while supposedly conditional, has exhibited lackluster monitoring. In contrast to the user funded programs, it appears government financed programs are less likely to ensure the provision of the service and may be implemented for political gain rather than environmental outcomes.

\subsection{Broad Themes}

Concerning transaction costs, those which are classified as low tend to be the programs which are funded by the central government. The CRP program in the U.S. comes in at only $1 \%$ of the programs cost. This is extremely low, compared to the $66 \%$ in the Nhambita project. Being one of the few programs explored in a developed world setting, the low transaction cost is strongly related to the pre-existing institutions and pre-existing data. In addition, the scale of the project keeps down the transaction costs as a percentage. In 2004, the program expended \$1850 million of which \$15.5 million was for transaction costs (Claassen, Cattaneo \& Johansson 2008). However, the generalization of transaction costs being high for users and low for governments does not hold completely across our sample. For instance, the SLCP in China is government run and has high transaction costs, though this is a very large program lacking the infrastructure already existing in the US. In contrast, there does appear to be a positive relationship between transaction costs and the public nature of the good. That is, transaction costs are lowest when the programs target club goods, such as watershed services, and highest when targeting a global public good like carbon sequestration.

Another important issue is the role of property rights. Notably, many projects exist where the service is already legally required. It highlights the potential use of payments rather than sanctions because the current institutional structure does not provide proper enforcement of the existing laws. ${ }^{16}$ The places where users are financing the program exhibit the sufficiency of $d e$ facto rights, as they are paying for a service that is required by law (Wunder \& Albán 2008). Some programs do allow communal land to enroll e.g., PSA-CABSA and PSAH in Mexico (Corbera, Soberanis \& Brown 2009, García-Amado et al. 2011, Muñoz-Piña et al,. 2008). Other programs also allow those with incomplete or insecure property rights to participate, e.g., CRP in the U.S. and Costa Rica's PSA (Claassen, Cattaneo \& Johansson 2008, Zbinden \& Lee 2005).

\footnotetext{
${ }^{15}$ Five percent of the land is actually measured to quantify the carbon sequestration and extrapolated to the rest of the sample.

${ }^{16}$ This is certainly the logic for revising the existing forest code in Brazil.
} 
The extant evidence indicates that full private property rights are not necessary for successful PES programs and that communal and incomplete rights are sufficient in many cases.

\section{REDD+ Implications}

REDD+ offers an alternative method to reduce carbon levels by increasing the capacity of the "sink" to absorb carbon rather than reducing actual emissions. As discussed above, the issue with carbon sequestration is that it is a pure public good, leading to the under provision of the service. However, it is estimated that $1 / 5$ of global emissions of greenhouse gas are attributable to forest degradation, making it important to consider in policy discussions (Palmer 2011). In order to provide incentives for nations, and ultimately communities and individuals, to reduce their own carbon footprint, certain institutional structures must be present to create effective provision of the good. The length of contracts is also important because while a unit of carbon not emitted is forever out of the atmosphere, one which is sequestered will eventually return.

\subsection{Exclusion Creation}

Capping emissions and creating permits creates an instrument tied to carbon emissions which are now rival and excludable (Farley et al. 2010). Alternatively, developed countries could enact a carbon tax. So long as offsets are permitted, the result will be the same and REDD+ will allow developing countries to provide emission reductions through land management. Economically, increasing the source of possible emission reductions will not make the program more expensive and may make it more cost effective.

\subsection{Incentive Compatibility}

Along with concerns of additionality, conditionality and monitoring are particularly large issues in the international setting of carbon. This is largely due to the nature of the excludable and rival certification. Only the piece of paper which gives credit for emissions reduction is valuable to the purchaser (Alston \& Andersson 2011, Swallow \& Meinzen-Dick 2009). Unlike user funded programs in watershed services, where the service is actually desired, the carbon reduction itself

remains a public good. ${ }^{17}$ In this sense, the purchaser of the service has no incentive to report the provider's failure to deliver the service. Naturally, the provider has no incentive to report themselves either, as they wish to keep the money received. From the contracting parties involved, then, they have little interest in monitoring the activity and ensuring the service is provided. Even if the carbon rights are decoupled from the land and owned by the buyer, making them liable for a failure of provision and thus some incentive to monitor activities, without a third-party verifying, the incentive remains incompatible.

\footnotetext{
${ }^{17}$ Blackman \& Woodward (2010) question the efficacy of user-funded programs as well. Looking at Costa Rican watersheds, hydroelectric power plants may be voluntarily paying for services for political reasons, not the actual environmental service.
} 


\subsection{PES Mechanisms}

PES is a popular mechanism to achieve the goals of REDD+. Given that offsets are allowed in the regulated nations, positive incentives are the only way to induce non-regulated countries to participate. One nation cannot regulate another due to sovereignty issues. Furthermore, while it is feasible for a nation to purchase land in another country, and thus have the right to reduce emissions themselves, this often is viewed as a threat to sovereignty (Vatn 2010). However, payments can provide positive incentives that lead landowners to engage in conservation now that they receive the benefits for the service they are providing. Policy makers view PES favorably for implementing REDD+ for this reason. However, there remains considerable debate whether these PES schemes will provide actual carbon sequestration and whether the transaction costs involved will erode the mutual benefits.

Briefly returning to empirical results, the evidence is not favorable towards effectiveness. PES schemes have not achieved a lot of additionality of carbon sequestration and in some cases there is little evidence that land use even changed. The large hurdle is that of unclear property rights and large transaction costs stemming from costly negotiation (not getting de facto and de jure rights holders at the table), monitoring and enforcement costs. Users funded a majority of the carbon PES schemes included in our study, demonstrating the effectiveness in policies creating exclusionary goods. However, they are also plagued by high transaction costs and it remains unclear that sufficient monitoring and verification will occur.

\subsection{REDD+ Policy}

In order to achieve true reductions in a cost effective manner, REDD+ PES schemes can be informed by theory and empirics. Nesting levels of provision is one avenue which can increase the additionality while providing more effective monitoring and competition to reduce costs. By negotiating at the nation level, governments can economize on the transaction costs. At this level, conditionality can be on actual aggregate performance. This process still needs to be verified by an independent third-party. However, once this criterion is established, monitoring at the lower levels is incentive compatible. The state has the incentive to allocate the funds to successful projects. This competition for funds by local and regional governments can also provide cost-effective mitigation, similar to the benefits of an auction in alleviating information asymmetries. The nested approach also eliminates tenure issues at the international level, as the nation certainly has rights to its own land. The nation state may in turn assign property rights and monitoring to lower sub-national and local units of governance which should reduce overall transaction costs. Potentially, REDD+ could provide further benefits by giving governments of developing countries incentives to establish institutions necessary to deliver the service (Agrawal, Nepstad \& Chhatre 2011). Institution building in turn could be a public good for the developing countries. Even if nestedness is not utilized, targeting communal lands or large private owners is important. Larger portions of land provide savings in transaction costs and reduce the possibility of leakage. 


\section{Conclusion}

PES is subject to many transaction costs. We expect these to increase moving from watershed services to biodiversity protection to carbon sequestration based mainly on physical attributes of these services. Existing empirical literature confirms our prediction. While our analysis does not look favorably on the effectiveness of a PES type scheme to initiate REDD+, we do present some steps which could reduce transaction costs and increase the probability of success. More work needs to be done to assess whether parties engaged in REDD+ initiatives foresee the downstream transaction costs and negotiate ex-ante to lessen the otherwise opportunistic behavior.

We also stress that the bulk of PES programs are relatively new and that with experimentation and learning the results should improve. For now the jury is still out yet there is reason for optimism over time especially with regard to local club goods. In addition, PES programs should not be viewed in isolation from other programs for sustainable management. Indeed, we encourage the environmental community to consider PES programs as complements rather than substitutes for other programs aimed at sustainable management.

\section{Literature Cited}

Agrawal, A., Nepstad, D. \& Chhatre, A. 2011, "Reducing Emissions from Deforestation and Forest Degradation", Annual Review of Environment and Resources, vol. 36, no. 1, pp. 373396.

Akiefnawati, R., Villamor G.B., Zulfikar, F., Budisetiawan, I., Mulyoutami, E., Ayat, A. \& Van Noordwijk, M. 2010, "Stewardship Agreement to Reduce Emissions from Deforestation and Degradation (REDD): Case Study from Lubuk Beringin's Hutan Desa, Jambi Province, Sumatra, Indonesia", International Forestry Review, vol. 12, no. 4, pp. 349-360.

Alston, L., Harris, E. \& Mueller, B. 2012, "The Development of Property Rights on Frontiers: Endowments, Norms, and Politics", Journal of Economic History, vol. 72, no. 3, pp. 741.

Alston, L.J. \& Andersson, K. 2011, "Reducing Greenhouse Gas Emissions by Forest Protection; The Transaction Costs of Implementing REDD", Climate Law, vol. 2, no. 2, pp. 281-289.

Andersson, K. \& Richards, K. 2001, "Implementing an International Carbon Sequestration Program: Can the Leaky Sink be Fixed?” Climate Policy. Vol 1, no.2,, pp. 173-188.

Blackman, A. \& Woodward, R.T. 2010, "User financing in a national payments for environmental services program: Costa Rican hydropower", Ecological Economics, vol. 69, no. 8, pp. 1626-1638.

Börner, J., Wunder, S., Wertz-Kanounnikoff, S., Tito, M.R., Pereira, L. \& Nascimento, N. 2010, "Direct conservation payments in the Brazilian Amazon: Scope and equity implications", Ecological Economics, vol. 69, no. 6, pp. 1272-1282. 
Bowles, S. 2008, "Policies designed for self-interested citizens may undermine" the moral sentiments": Evidence from economic experiments", Science, vol. 320, no. 5883, pp. 16051609.

Busch, J., Lubowski, R.N., Godoy, F., Steininger, M., Yusuf, A.A., Austin, K., Hewson, J., Juhn, D., Farid, M. \& Boltz, F. 2012, "Structuring economic incentives to reduce emissions from deforestation within Indonesia", Proceedings of the National Academy of Sciences, vol. 109, no. 4, pp. 1062-1067.

Claassen, R., Cattaneo, A. \& Johansson, R. 2008, "Cost-effective design of agri-environmental payment programs: U.S. experience in theory and practice", Ecological Economics, vol. 65, no. 4, pp. 737-752.

Clements, T., John, A., Nielsen, K., An, D., Tan, S. \& Milner-Gulland, E.J. 2010, "Payments for biodiversity conservation in the context of weak institutions: Comparison of three programs from Cambodia", Ecological Economics, vol. 69, no. 6, pp. 1283-1291.

Coase, R.H. 1974, "The Lighthouse in Economics", JL \& Econ., vol. 17, pp. 357.

Coase, R.H. 1960, "The Problem of Social Cost", Journal of Law and Economics, vol. 3, pp. 144.

Coomes, O.T., Grimard, F., Potvin, C. \& Sima, P. 2008, "The fate of the tropical forest: Carbon or cattle?", Ecological Economics, vol. 65, no. 2, pp. 207-212.

Corbera, E., Soberanis, C.G. \& Brown, K. 2009, "Institutional dimensions of Payments for Ecosystem Services: An analysis of Mexico's carbon forestry programme", Ecological Economics, vol. 68, no. 3, pp. 743-761.

Dobbs, T.L. \& Pretty, J. 2008, "Case study of agri-environmental payments: The United Kingdom", Ecological Economics, vol. 65, no. 4, pp. 765-775.

Engel, S., Pagiola, S. \& Wunder, S. 2008, "Designing payments for environmental services in theory and practice: An overview of the issues", Ecological Economics, vol. 65, no. 4, pp. 663-674.

Engel, S. \& Palmer, C. 2008, "Payments for environmental services as an alternative to logging under weak property rights: The case of Indonesia", Ecological Economics, vol. 65, no. 4, pp. 799-809.

Farley, J., Aquino, A., Daniels, A., Moulaert, A., Lee, D. \& Krause, A. 2010, "Global mechanisms for sustaining and enhancing PES schemes", Ecological Economics, vol. 69, no. 11, pp. 2075-2084. 
Fisher, B., Kulindwa, K., Mwanyoka, I., Turner, R.K. \& Burgess, N.D. 2010, "Common pool resource management and PES: Lessons and constraints for water PES in Tanzania", Ecological Economics, vol. 69, no. 6, pp. 1253-1261.

García-Amado, L.R., Pérez, M.R., Escutia, F.R., García, S.B. \& Mejía, E.C. 2011, "Efficiency of Payments for Environmental Services: Equity and additionality in a case study from a Biosphere Reserve in Chiapas, Mexico", Ecological Economics, vol. 70, no. 12, pp. 23612368.

Gómez-Baggethun, E., de Groot, R., Lomas, P.L. \& Montes, C. 2010, "The history of ecosystem services in economic theory and practice: From early notions to markets and payment schemes", Ecological Economics, vol. 69, no. 6, pp. 1209-1218.

Groom, B. \& Palmer, C. 2012, "REDD+ and rural livelihoods", Biological Conservation, vol. 154, pp. 42-52.

Hegde, R. \& Bull, G.Q. 2011, "Performance of an agro-forestry based Payments-forEnvironmental-Services project in Mozambique: A household level analysis", Ecological Economics, vol. 71 pp. 122-130.

Hoang, M.H., Do, T.H., Pham, M.T., van Noordwijk, M. \& Minang, P.A. 2012, "Benefit distribution across scales to reduce emissions from deforestation and forest degradation (REDD ) in Vietnam", Land Use Policy, In Press.

Honey-Roses, J., Baylis, K. \& Ramirez , M.I. 2011, "A Spatially Explicit Estimate of Avoided Forest Loss; Una Estimación Espacialmente Explícita de la Pérdida de Bosque Evitada", Conservation Biology, vol. 25, no. 5, pp. 1032-1043.

Karsenty, A., Vogel, A. \& Castell, F. 2012, "“Carbon rights”, REDD and payments for environmental services", Environmental Science \& Policy, In Press.

Kerr, J., Vardhan, M. \& Jindal, R. 2012, "Prosocial behavior and incentives: Evidence from field experiments in rural Mexico and Tanzania", Ecological Economics, vol. 73, pp. 220-227.

Kosoy, N., Martinez-Tuna, M., Muradian, R. \& Martinez-Alier, J. 2007, "Payments for environmental services in watersheds: Insights from a comparative study of three cases in Central America", Ecological Economics, vol. 61, no. 2-3, pp. 446-455.

Kroeger, T. \& Casey, F. 2007, "An assessment of market-based approaches to providing ecosystem services on agricultural lands", Ecological Economics, vol. 64, no. 2, pp. 321332.

Landell-Mills, N. \& Porras, I.T. 2002, Silver bullet or fools' gold?: a global review of markets for forest environmental services and their impact on the poor, IIED London. 
Locatelli, B., Rojas, V. \& Salinas, Z. 2008, "Impacts of payments for environmental services on local development in northern Costa Rica: A fuzzy multi-criteria analysis", Forest Policy and Economics, vol. 10, no. 5, pp. 275-285.

Lyster, R. 2011, "REDD+, transparency, participation and resource rights: the role of law", Environmental Science \& Policy, vol. 14, no. 2, pp. 118-126.

Mahanty, S., Suich, H. \& Tacconi, L. 2012 "Access and benefits in payments for environmental services and implications for REDD+: Lessons from seven PES schemes", Land Use Policy, In Press.

Muñoz-Piña, C., Guevara, A., Torres, J.M. \& Braña, J. 2008, "Paying for the hydrological services of Mexico's forests: Analysis, negotiations and results", Ecological Economics, vol. 65, no. 4, pp. 725-736.

Nelson, F., Foley, C., Foley, L.S., Leposo, A., Loure, E., Perterson, D.D., Peterson, M., Peterson, T., Sachedina, H. \& Williams, A. 2010, "Payments for Ecosystem Services as a Framework for Community-Based Conservation in Northern Tanzania; Pago de los Servicios Ecosistémicos como Marco de Referencia para la Conservación Basada en Comunidades en el Norte de Tanzania", Conservation Biology, vol. 24, no. 1, pp. 78-85.

Ostrom, E. 2009, "A General Framework for Analyzing Sustainability of Social-Ecological Systems", Science, vol. 325, no. 5939, pp. 419-422.

Pagiola, S. 2008, "Payments for environmental services in Costa Rica", Ecological Economics, vol. 65, no. 4, pp. 712-724.

Palmer, C. 2011, "Property rights and liability for deforestation under REDD+: Implications for 'permanence’ in policy design", Ecological Economics, vol. 70, no. 4, pp. 571-576.

Pfaff, A., Robalino, J.A. \& Sanchez-Azefeifa, G.A. 2008, "Payments for Environmental Services: Empirical Analysis for Costa Rica", Working Paper Series: Terry Sanford Institute of Public Policy, vol. SAN08-05.

Richards, K. \& Andersson, K. 2001, "The leaky sink: persistent obstacles to a forest carbon sequestration program based on individual projects", Climate Policy, vol. 1, no. 1, pp. 4154.

Sierra, R. \& Russman, E. 2006, "On the efficiency of environmental service payments: A forest conservation assessment in the Osa Peninsula, Costa Rica", Ecological Economics, vol. 59, no. 1, pp. 131-141.

Stickler, C.M., Nepstad, D.C., Coe, M.T., McGrath, D.G., Rodrigues, H.O., Walker, W.S., Soares-Filho, B.S. \& Davidson, E.A. 2009, "The potential ecological costs and cobenefits of REDD: a critical review and case study from the Amazon region", Global Change Biology, vol. 15, no. 12, pp. 2803-2824. 
Swallow, B. \& Meinzen-Dick, R. 2009, "Payments for Environmental Services: Interactions with Property Rights and Collective Action" in Institutions and Sustainability, eds. V. Beckman \& M. Padmanabhan, Springer, Netherlands, pp. 243-265.

Turpie, J.K., Marais, C. \& Blignaut, J.N. 2008, "The working for water programme: Evolution of a payments for ecosystem services mechanism that addresses both poverty and ecosystem service delivery in South Africa", Ecological Economics, vol. 65, no. 4, pp. 788-798.

Van Hecken, G., Bastiaensen, J. \& Vásquez, W.F. 2012, "The viability of local payments for watershed services: Empirical evidence from Matiguás, Nicaragua", Ecological Economics, vol. 74, no. 0, pp. 169-176.

Van Noordwijk, M. \& Leimona, B. 2010, "Principles for Fairness and Efficiency in Enhancing Environmental Services in Asia: Payments, Compensation, or Co-Investment", Ecology and Society, vol. 15, no. 4, pp. Art. 17.

Vatn, A. 2010, "An institutional analysis of payments for environmental services", Ecological Economics, vol. 69, no. 6, pp. 1245-1252.

White, A. \& Martin, A. 2002, Who owns the world's forests? Forest tenure and public forests in transition, Washington, DC, USA.

Wunder, S. 2006, "Are Direct Payments for Environmental Services Spelling Doom for Sustainable Forest Management in the Tropics?", Ecology and Society, vol. 11, no. 2, pp. Art. 23.

Wunder, S. \& Albán, M. 2008, "Decentralized payments for environmental services: The cases of Pimampiro and PROFAFOR in Ecuador", Ecological Economics, vol. 65, no. 4, pp. 685698.

Wunder, S., Engel, S. \& Pagiola, S. 2008, "Taking stock: A comparative analysis of payments for environmental services programs in developed and developing countries", Ecological Economics, vol. 65, no. 4, pp. 834-852.

Yin, R. \& Zhao, M. 2012, "Ecological restoration programs and payments for ecosystem services as integrated biophysical and socioeconomic processes-China's experience as an example", Ecological Economics, vol. 73, pp. 56-65.

Zbinden, S. \& Lee, D.R. 2005, "Paying for Environmental Services: An Analysis of Participation in Costa Rica’s PSA Program", World Development, vol. 33, no. 2, pp. 255-272. 


\section{Table 1: Empirical Studies}

\begin{tabular}{|c|c|c|c|c|c|c|}
\hline Program & Country & ES & Funding & $\begin{array}{l}\text { De Jure } \\
\text { illegal }\end{array}$ & Conditionality & $\begin{array}{c}\text { Transaction } \\
\text { Costs }\end{array}$ \\
\hline PSA & Costa Rica & All & gov. & no & high & $15 \%$ \\
\hline
\end{tabular}

\begin{tabular}{|c|c|c|c|c|c|c|}
\hline Ecotourism & Cambodia & Biodiversity & gov. & yes & yes-output & high \\
\hline $\begin{array}{l}\mathrm{Ag} \\
\text { Certification }\end{array}$ & Cambodia & Biodiversity & gov. & yes & yes-output & high \\
\hline Monitoring & Cambodia & Biodiversity & gov. & yes & yes-input & low \\
\hline $\begin{array}{l}\text { Biosphere } \\
\text { Reserve }\end{array}$ & Mexico & Biodiversity & gov. & yes & yes-outcome & unknown \\
\hline Single Contract & Tanzania & Biodiversity & user & no & yes & low \\
\hline CSS & $\begin{array}{l}\text { United } \\
\text { Kingdom }\end{array}$ & $\begin{array}{l}\text { Biodiversity } \\
\text { /landscape }\end{array}$ & gov. & no & yes & $18 \%$ \\
\hline CLP & Mozambique & Carbon & user & no & low & $66 \%$ \\
\hline PSA-CABSA & Mexico & Carbon & gov. & no & low & $30-50 \%$ \\
\hline Profafor & Ecuador & Carbon & user & yes & $\begin{array}{l}\text { yes-lower } \\
\text { community }\end{array}$ & $25 \%$ \\
\hline PASOLAC & $\begin{array}{l}\text { Central } \\
\text { America }\end{array}$ & Water & user & no & low & high \\
\hline PSAH & Mexico & Water & gov. & no & yes & $4 \%$ \\
\hline Pimampiro & Ecuador & Water & user & yes & yes-input & $17 \%$ \\
\hline WFW & South Africa & Water & gov. & yes & yes-input & low \\
\hline SLCP & China & Water & gov. & no & yes-retired & high \\
\hline CRP & $\begin{array}{l}\text { United } \\
\text { States }\end{array}$ & $\begin{array}{l}\text { Water/ } \\
\text { wildlife }\end{array}$ & gov. & no & $\begin{array}{l}\text { yes/low } \\
\text { inspection }\end{array}$ & $1 \%$ \\
\hline
\end{tabular}


Table 1: Empirical Studies, Continued

\begin{tabular}{|c|c|c|c|c|c|c|}
\hline Program & Paper & Additionality & Leakage & $\begin{array}{c}\text { Poverty } \\
\text { Reduction }\end{array}$ & $\begin{array}{c}\text { Covers } \\
\text { Opportunity } \\
\text { Cost }\end{array}$ & Outcome \\
\hline \multirow[t]{5}{*}{ PSA } & $\begin{array}{l}\text { Locatelli, Rojas \& } \\
\text { Salinas (2008) }\end{array}$ & $\mathrm{n} / \mathrm{a}$ & $\mathrm{n} / \mathrm{a}$ & no & no & Positive \\
\hline & $\begin{array}{l}\text { Pfaff, Robalino \& } \\
\text { Sanchez-Azefeifa } \\
\text { (2008) }\end{array}$ & low & $\mathrm{n} / \mathrm{a}$ & $\mathrm{n} / \mathrm{a}$ & $\mathrm{n} / \mathrm{a}$ & $\begin{array}{l}\text { Marginally } \\
\text { positive }\end{array}$ \\
\hline & Zbinden \& Lee (2005) & low & possible & no & $\mathrm{n} / \mathrm{a}$ & mixed \\
\hline & $\begin{array}{l}\text { Sierra \& Russman } \\
\text { (2006) }\end{array}$ & low & possible & $\mathrm{n} / \mathrm{a}$ & $\mathrm{n} / \mathrm{a}$ & $\begin{array}{l}\text { Marginally } \\
\text { positive }\end{array}$ \\
\hline & Pagiola (2008) & low & $\mathrm{n} / \mathrm{a}$ & no & $\mathrm{n} / \mathrm{a}$ & Positive \\
\hline Ecotourism & $\begin{array}{l}\text { Clements et al. } \\
\text { (2010) }\end{array}$ & yes & $\mathrm{n} / \mathrm{a}$ & $\mathrm{n} / \mathrm{a}$ & high & Positive \\
\hline $\begin{array}{l}\mathrm{Ag} \\
\text { Certification }\end{array}$ & $\begin{array}{l}\text { Clements et al. } \\
\text { (2010) }\end{array}$ & yes & $\mathrm{n} / \mathrm{a}$ & $\mathrm{n} / \mathrm{a}$ & high & Positive \\
\hline Monitoring & $\begin{array}{l}\text { Clements et al. } \\
\text { (2010) }\end{array}$ & yes & $\mathrm{n} / \mathrm{a}$ & $\mathrm{n} / \mathrm{a}$ & high & Positive \\
\hline $\begin{array}{l}\text { Biosphere } \\
\text { Reserve }\end{array}$ & $\begin{array}{l}\text { Honey-Roses, Baylis } \\
\text { \& Ramirez (2011) }\end{array}$ & yes & no & $\mathrm{n} / \mathrm{a}$ & $\mathrm{n} / \mathrm{a}$ & Positive \\
\hline $\begin{array}{l}\text { Single } \\
\text { Contract }\end{array}$ & Nelson et al. (2010) & likely & no & no & likely & Positive \\
\hline CSS & $\begin{array}{l}\text { Dobbs \& Pretty } \\
(2008)\end{array}$ & yes & $\begin{array}{l}\text { within } \\
\text { farm }\end{array}$ & no & $\mathrm{n} / \mathrm{a}$ & Positive \\
\hline \multirow[t]{2}{*}{ CLP } & Hegde \& Bull (2011) & $\mathrm{n} / \mathrm{a}$ & $\mathrm{n} / \mathrm{a}$ & no & yes & positive \\
\hline & $\begin{array}{l}\text { Groom \& Palmers } \\
\text { (2012) }\end{array}$ & likely & likely & likely & yes & positive \\
\hline PSA-CABSA & $\begin{array}{l}\text { Corbera, Soberanis \& } \\
\text { Brown (2009) }\end{array}$ & yes & $\mathrm{n} / \mathrm{a}$ & $\mathrm{n} / \mathrm{a}$ & yes & Positive \\
\hline Profafor & $\begin{array}{l}\text { Wunder \& Albán } \\
\text { (2008) }\end{array}$ & yes & low & yes & $\mathrm{n} / \mathrm{a}$ & Positive \\
\hline PASOLAC & Kosoy et al. (2007) & low & low & unlikely & no & Positive \\
\hline PSAH & $\begin{array}{l}\text { Muñoz-Piña et al. } \\
\text { (2008) }\end{array}$ & low & some & yes & $\mathrm{n} / \mathrm{a}$ & $\begin{array}{l}\text { Marginally } \\
\text { positive }\end{array}$ \\
\hline Pimampiro & $\begin{array}{l}\text { Wunder \& Albán } \\
\text { (2008) }\end{array}$ & yes & none & $\mathrm{n} / \mathrm{a}$ & $\mathrm{n} / \mathrm{a}$ & Positive \\
\hline WFW & $\begin{array}{l}\text { Turpie, Marais \& } \\
\text { Blignaut (2008) }\end{array}$ & yes & none & yes & yes & Positive \\
\hline \multirow[t]{2}{*}{ SLCP } & $\begin{array}{l}\text { Groom \& Palmers } \\
\text { (2012) }\end{array}$ & yes & potential & yes & yes & $n / a$ \\
\hline & Yin \& Zhao (2012) & yes & $\mathrm{n} / \mathrm{a}$ & $\mathrm{n} / \mathrm{a}$ & $\mathrm{n} / \mathrm{a}$ & Positive \\
\hline CRP & $\begin{array}{l}\text { Claassen, Cattaneo \& } \\
\text { Johansson (2008) }\end{array}$ & yes & $20 \%$ & $\mathrm{n} / \mathrm{a}$ & yes-bidding & Positive \\
\hline
\end{tabular}

